УДК 663.26 - 045.023 : $658.589: 338.439 .5$

DOI: $10.15673 /$ fie.v10i3.1060

Лагодієнко В.В.

доктор економічних наук, професор

E-mail: volodymyr@wiktoriya.com
Голодонюк О.М.

старший викладач

E-mail: kaf.mpit@gmail.com

Мільчева В.В.

аспірант

кафедра маркетингу, підприємництва і торгівлі

Одеська національна академія харчових технологій

вул. Канатна, 112, м. Одеса, Україна, 65039

E-mail: milchewa.v@gmail.com

\title{
СТРАТЕГІЧНІ РІШЕННЯ ПРОСУВАННЯ НА РИНОК ІННОВАЦІЙНОГО ПРОДУКТУ ЗІ ВТОРИННОЇ СИРОВИНИ ВИНОРОБСТВА
}

В даній статті розглянуто процес формування стратегічних рішень просування на ринок інноваційного продукту зі вторинної сировини виноробства на прикладі ПрАТ «Одесавинпром», розроблено чотири функціональні стратегії згідно з кожним елементом комплексу маркетингу для підприємства, наведений приклад вдало організованої рекламної кампанії для просування нового товару виробника. Нестабільність ринкового середовища, жорсткість та мінливість його зовнішніх та внутрішніх фракторів потребують точного та розсудливого прогнозу результатів діяльності підприємства. Низькі показники розвитку інноваційної сфрери в Україні порівняно з підприємствами інших країн світу є причиною низького рівня конкурентоспроможності і, як результат, нестійкого економічного розвитку. Управління інноваційною діяльністю підприємства в першу чергу передбачає обов'язкове безупинне вдосконалення виробничого процесу шляхом пошуку, відбору, розробки та впровадження інноваційних концепцій, формування банку інноваційних ідей та методів їх результативної реалізації, виявлення найгостріших проблем інноваційного розвитку та шляхів їх подолання, тощо [3].

Таким чином, правильно обрана стратегія $є$ не тільки результатом, але й ефективним механізмом плідного стратегічного планування. Вона мобілізує використання науково-технічного, виробничотехнологічного, фрінансово-економічного, соціального і організаційного потенціалу підприємства в визначених напрямках, що є основою його конкурентоспроможності.

Ключові слова: стратегія, реклама, інноваційний продукт, сироп, ПрАТ «Одесавинпром», вторинна сировина виноробства.

This work is licensed under a Creative Commons Attribution 4.0 International License http://creativecommons.org/licenses/by/4.0/

Постановка проблеми та її зв'язок з важливими науковими та практичними завданнями. В даний час інновації мають величезне значення для економіки країни. Для вітчизняних фірм впровадження у виробництво інноваційних товарів все частіше стає вигідним способом протистояти в конкурентній боротьбі з іншими товаровиробниками. Також великого значення набуває здатність підприємства пристосуватися до нововведень.

Щоб полегшити процес виведення на ринок інноваційного продукту, підприємства використовують стратегічне планування, яке допомагає ефективно вирішити поставлені виробником проблеми. За допомогою правильно розробленої стратегії можна визначити термін на способи впровадження інновації та складові інноваційного проекту. В більшості випадків, при ефективному плануванні, інновації сприяють отриманню додаткового прибутку, який є ціллю діяльності більшості виробничих підприємств [1].

Обрані стратегічні рішення просування на ринок інноваційного продукту будуть впливати на конкурентоспроможність, стійкість в умовах ринкової економіки, підвищенню прибутку, задоволенню потреб потенційних клієнтів. Вдало розроблена стратегія нововведення, що досліджується, є запорукою успіху та фінансової стабільності підприємства.

Аналіз останніх публікацій по проблемі. Дану проблему досліджували відомі вітчизняні та зарубіжні вчені, такі як: Д. Аакер, І. Ансофф, М. Портер, А. Градов, Р.А. Фатхутдінов, А.П. Гречан, А.В. Гриньов, С.М. Ілляшенко, Д.М. Черваньов, Н. Чухрай та ін.

Формулювання цілей дослідження. Метою даного дослідження $є$ ефективне стратегічне планування процесу виведення на ринок інноваційного продукту, а саме біологічно активної добавки, отриманої шляхом переробки вторинної сировини виноробства (гребенів винограду).

Виклад основних результатів та їх обгрунтування. У наш час, коли екологічна проблема в країні набуває все більшої актуальності через неякісну воду, забруднене повітря, деградацію земельних ре 
сурсів та побутові відходи, питання якості продуктів харчування на полицях магазинів вимагає більшої уваги 3 боку споживачів. А враховуючи й те, що останнім часом швидке та бездумне харчування лише задля задоволення почуття голоду стало нормою, слід ретельніше слідкувати за своїм здоров'ям та їсти свідомо, використовуючи високоякісні корисні продукти.

Саме тому, дослідивши маркетингову діяльність найстарішого та легендарного підприємства у м. Одесі, а саме ПрАТ «Одесавинпром», для покращення фінансового становища та укріплення своїх конкурентних переваг виробнику було запропоновано диверсифікувати товарний портфель та розширити асортимент продукції, що виробляється на заводі, інноваційним товаром, отриманим шляхом перероблення вторинної сировини виноробства(гребенів винограду).
Для ефективного просування запропонованого товару на ринок було вирішено розробити чотири функціональні стратегії згідно 3 кожним елементом комплексу маркетингу для ПрАТ «Одесавинпром».

Товарна стратегія. Для ПрАТ «Одесавинпром» головною складовою товарної стратегії є розробка та виведення на ринок високоякісної продукції, яка б не тільки приносила підприємству бажаний прибуток, а й в повній мірі задовольняла запити споживачів та відповідала усім встановленим стандартам.

Для удосконалення товарної політики підприємства було запропоновано розширити асортимент, шляхом впровадження у виробництво інноваційного продукту 3 високим вмістом біологічно активних сполук.

Існує декілька різновидів даної категорії продуктів (рис. 1). Зупинимо свою увагу лише на одному 3 них, а саме на біологічно активній добавці (сиропі).

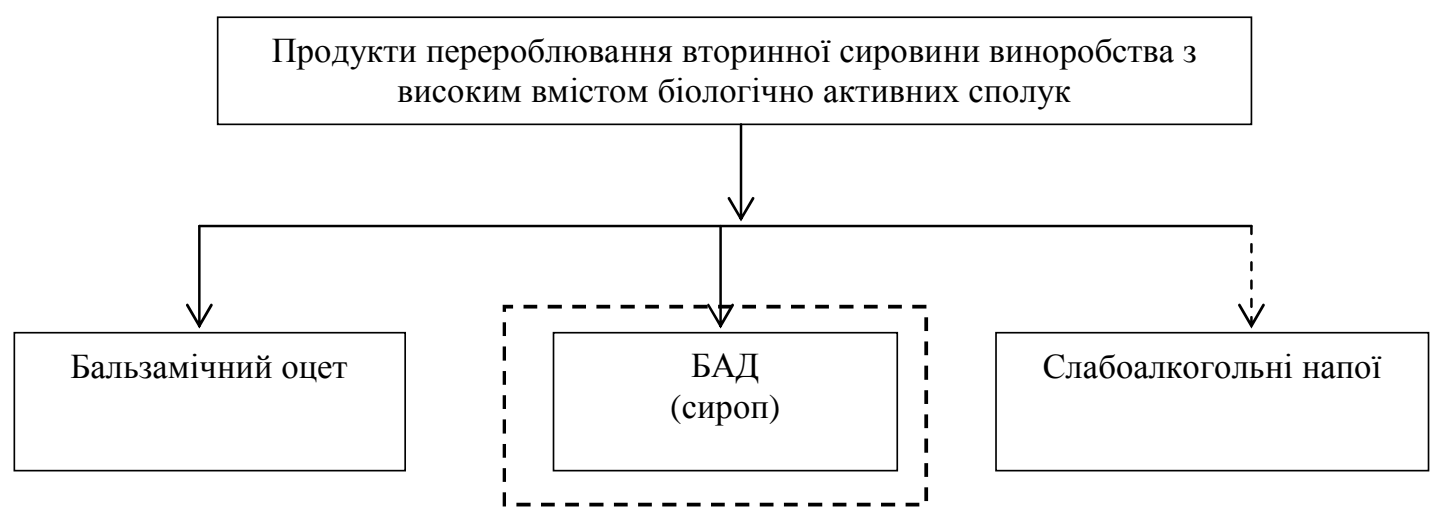

Рис. 1. Різновиди продуктів перероблювання вторинної сировини* * авторська розробка

Біологічно активна добавка (сироп) або бальзам - природний еліксир життя і молодості на основі винограду. Він зміцнює імунітет, поліпшує самопочуття і допомагає позбутися багатьох хвороб.

Це продукт нового покоління, який значно підвищує якість життя людей в умовах несприятливої економічної й екологічної обстановки. Завдяки своїм корисним властивостям даний товар отримав назву «Здоровіт», що в перекладі означає «здорове життя».

Цей унікальний продукт виробляється виключно з натуральної сировини - гребенів винограду. У його складі немає консервантів, барвників і ГМО.

Представлений сироп має широкий спектр дії, працює на клітинному рівні і використовується для профілактики і лікування понад 60-ти захворювань.

«Здоровіт» - сироп, призначений для створення оптимальних дієтологічних умов регулювання антиоксидантного балансу організму. Він сприяе уповільненню процесів передчасного старіння та відновленню структури хромосом, пошкоджених іонізувальним випромінюванням [6].
«Зміинювати здоров'я і віддаляти старість» - такою є мета представленого проекту! За результатами опитування споживачів, було вирішено продавати «Здоровіт» в пляшці об'ємом 250 мл.

Для підтвердження правильності обраного обсягу виробництва сиропу необхідно розрахувати ємність ринку його збуту в м. Одесі та Одеській області.

Ємність ринку розрахуємо за наступною формулою:

$$
\mathrm{E}=\mathrm{Ч}_{\mathrm{H}} \cdot \mathrm{K}_{1} \cdot \mathrm{K}_{2} \cdot \text { ЧВП } \cdot \mathrm{i}
$$

де Е - ємність ринку

$\mathrm{Ч}_{\mathrm{H}}-$ чисельність населення м. Одеси та

Одеської області, чол.;

$\mathrm{K}_{1}$ - частка опитуваних, які погодилися вживати продукт;

$\mathrm{K}_{2}$ - частка населення потрібного віку;

ЧВП - частота вживання продукту за рік;

$\mathrm{i}$ - інтенсивність споживання продукту за

рік.

Отримані результати покажемо у зведеному у таблицю 1 вигляді. 
Таблиця 1

Смність ринку збуту інноваційного продукту для дитячого та дорослого населення*

\begin{tabular}{|c|c|}
\hline Курс вживання 2 тижні & Курс вживання 3 тижні \\
\hline $\mathrm{E}_{\text {дит }}=2945,67$ дал & $\mathrm{E}_{\text {дит }}=4418,51$ дал \\
$\mathrm{E}_{\text {дор }}=51687$ дал & $\mathrm{E}_{\text {дор }}=77530,5$ дал \\
\hline Разом: 54632,67 дал & Разом: 81949 дал \\
\hline
\end{tabular}

* авторська розробка

Проведені розрахунки визначили ємність ринку по сиропу «Здоровіт», який впроваджується у розмірі 54,6 тис. дал (при курсі вживання 2 тижні) та 81,9 тис. дал (при курсі вживання 3 тижні). Відштовхуючись 3 отриманих результатів закладаємо у план виробництва обсяг продукції у розмірі 36,6 тис. дал. Це свідчить про те, що підприємство має всі шанси виробляти значно більше сиропу, який буде мати успіх серед покупців, адже попит на цю продукцію перевищує пропозицію. Але, слід зазначити, що обраний обсяг виробництва запропоновано лише на перший рік реалізації товару на ринку, для того, щоб переконатися у бажанні споживачів купувати цей продукт та запобігти втратам у разі невдачі.

Якщо дані розрахунків підтвердяться, новий продукт буде вдало реалізуватися на ринку м. Одеси та Одеської області, а ПрАТ «Одесавинпром» отримає бажаний прибуток та стабільний фінансовий стан. Обсяги виробництва будуть збільшуватися, а ринок збуту розширюватися у межах країни, а в перспективі - і за кордоном.

Цінова стратегія. Підприємство, при встановлені ціни на новий інноваційний продукт, має можливість використовувати стратегію «зняття вершків», адже він $€$ товаром ринкової новизни, який не має аналогів на ринку. Ця стратегія орієнтована на те, що підприємство, використовуючи потужну рекламу, досягає високих фінансових результатів за рахунок реалізації свого товару за відносно високими цінами, які значно перевищують ціни виробництва. Ця стратегія гарна тим, що підприємство отримує можливість у короткий термін повернути витрачені кошти на розробку інноваційного продукту, його виробництво і просування та по можливості в майбутньому використовувати механізм зниження ціни для продуманого стимулювання збуту своєї продукції закордонним партнерам та споживачам українського ринку.

Але, враховуючи унікальні властивості товару, що пропонується та його соціальну значимість для оздоровлення українців, було вирішено при встановлені ціни керуватися стратегією «проникнення на ринок», яка передбачає вихід з товаром на ринок за відносно низькими цінами, які дозволять зробити його більш доступним для широкого кола споживачів.

Ця стратегія є найбільш безпечною, тому що зменшує ризик його провалу через незнання ставлення покупця до нового товару. За допомогою цієї стратегії підприємство матиме можливість виявити перспективи збуту нового продукту та знайти прийнятний рівень цін. Провівши необхідні розрахунки визначили, що роздрібна ціна пляшки складе 47,85 грн.
Збутова стратегія. Для реалізації продукції власного виробництва на території України ПрАТ «Одесавинпром» використовує власну збутову мережу.

Але, враховуючи специфіку та особливості виробництва і вжитку нового інноваційного сиропу «Здоровіт», для його просування підприємству рекомендується розширити дану мережу шляхом включення до неї додаткових ефективних каналів збуту.

Враховуючи вищесказане, рекомендуємо наступні канали збуту: аптеки, поліклініки, лікарні, санаторії, пологові будинки, будинки відпочинку, школи, дитячі садки, різні посередницькі організації дистриб'юторів та дилерів.

Комунікаиійна стратегія. Для вдалого просування інноваційного продукту «Здоровіт» на ринку України необхідно організувати рекламну кампанію.

Рекламна кампанія виступає як певне управління процесом руху товару на всіх етапах - перед продажем, у момент купівлі, під час і після закінчення процесу споживання [9].

При розробці ефективної рекламної кампанії виділяють наступні етапи:

1. Визначення иілььової контактної аудиторії. Вона може бути представлена окремими особами або всім суспільством. Цільовою аудиторією покупців продукту, що пропонується є люди, віком від 21 року. Хоча сироп «Здоровіт» рекомендований до вживання і дітям 3 двох років, але купівлю здійснюють все ж таки дорослі (батьки дитини).

2. Формування мети комунікації. Ціллю даної рекламної кампанії $є$ проінформувати покупців про появу нового продукту (його корисні властивості та сприятливий вплив на здоров'я людей) та переконати купити даний товар.

3. Створення звернення. Створення ефективного звернення $є$ основою успішної рекламної кампанії. У іiі основі лежить розробка змісту звернення, формування структури звернення, оформлення звернення і вибір оптимального джерела звернення. Маркетологи і рекламісти прагнуть створити унікальний заклик, тему, ідею або торгову пропозицію, яка б була конкурентоспроможною на ринку.

Для рекламної кампанії, що планується, розроблено три рекламних звернення (для кожного ЗМІ окремо).

- для білборду - ««Здоровіт» - здорове життя у ваших руках!»».

- для плакату - «Зміцнює здоров’я і віддаляє старість».

- для листівки - «Здорові діти - щаслива ciм'я!». 
4. Вибір каналів комунікаиії. Враховуючи особливості та характеристики створюваного інноваційного продукту, було прийнято рішення задіяти наступні носії реклами: телебачення, радіо, преса (реклама у газеті, плакатах та листівках), інтернет, зовнішня реклама (білборди).

Рекламна кампанія триватиме чотири місяці (з середини листопада до середини грудня та 3 лютого по квітень) впродовж року. Взимку, коли підвищена загроза захворювання грипом та весною, коли імунітет людини ослаблений та потребує додаткового укріплення. Для рекламування були обранні конкретні канали, а саме: «Україна», «PLUS», «Глас», «СТБ», «НТН», «ТЕТ», «Домашній», «Мега». Реклама на радіо транслюватиметься на «Просто радіо», «Європа+», «Хіт FM», «Ретро FM», «Наше радіо». Статті про корисність «Здоровіту» публікуватимуться в найбільш популярних виданнях: «Теленеделя», «Единственная» та «Отдохни». Також, було вирішено роздавати листівки, розмістити плакати та рекламу на білбордах міста.

Для того, щоб відібрати найбільш ефективні 3 представлених вище носіїв реклами, було розраховано суму рейтингових пунктів, обхват кількості людей цільової аудиторії і витрати на 1000 чоловік. Для виконання підрахунку кількісних показників при виборі найбільш ефективних носіїв реклами були використанні вихідні та експертні дані.

Аналіз отриманих даних дозволив зробити наступні висновки:

1. Найбільше значення показника питомих витрат на 1000 чоловік у таких медіа носї̈в:

а) реклама на телебаченні - Глас, Plus, TET, б) реклама на радіо - Хіт FM, Ретро FM;

в) реклама в журналі - «Единственная», «Отдохни».

Таким чином необхідно відмовитися від реклами у зазначених носіях та скорегувати дані медіаплану.

Враховуючи те, що найактуальнішим джерелом інформації на сьогодні є світова мережа Інтернет, необхідно зайнятися просуванням власного сайту та банерною рекламою нового продукту.

На сайті доцільно розмістити короткометражний фільм, в якому розповідається про розробку інноваційного товару, його корисні властивості та унікальність.

Цей маркетинговий хід залучить додаткових покупців, так як він носить в першу чергу інформаційний характер, а враховуючи те, що продукт новий, аналогів не існує, цей захід просто є необхідним кроком у плануємій рекламній кампанії.

Враховуючи розроблений медіа-план та строки проведення рекламної кампанії, розробимо план-графік розміщення реклами за допомогою різних її носіїв (табл. 2).

На телебаченні заплановано розмістити рекламу наступним чином: $з$ середини листопада до середини грудня, потім призупинити іiі показ і продовжити їі показ і продовжити з лютого по березень, щоб привернути увагу більшості споживачів.

Зовнішня реклама у вигляді білбордів буде однаково розподілена на чотири місяці.

Реклама на радіо буде транслюватися так само як і реклама на телебаченні.

Мега;

Таблиця 2

План-графік рекламної кампанії*

\begin{tabular}{|c|c|c|c|c|c|c|c|c|c|c|}
\hline \multirow{2}{*}{$\begin{array}{c}\text { Засоби масової } \\
\text { інформації }\end{array}$} & \multicolumn{2}{|c|}{ Листопад } & \multicolumn{2}{|c|}{ Грудень } & \multirow[b]{2}{*}{ Лютий } & \multirow[b]{2}{*}{ Березень } & \multirow[b]{2}{*}{ Квітень } & \multirow[b]{2}{*}{$\begin{array}{c}\text { Сума } \\
\text { виходів }\end{array}$} & \multirow[b]{2}{*}{$\begin{array}{l}\text { Ціна од., } \\
\text { грн. }\end{array}$} & \multirow[b]{2}{*}{$\begin{array}{l}\text { Сума ви- } \\
\text { трат, грн. }\end{array}$} \\
\hline & $\begin{array}{c}3 \\
\text { тиж }\end{array}$ & $\begin{array}{c}4 \\
\text { тиж }\end{array}$ & $\begin{array}{c}1 \\
\text { тиж }\end{array}$ & $\begin{array}{c}2 \\
\text { тиж }\end{array}$ & & & & & & \\
\hline \multicolumn{11}{|l|}{ Телебачення } \\
\hline Україна & \multicolumn{2}{|c|}{17} & \multicolumn{2}{|c|}{18} & 35 & 35 & 35 & 140 & 820,00 & 114800 \\
\hline СТБ & \multicolumn{2}{|c|}{17} & \multicolumn{2}{|c|}{18} & 35 & 35 & 35 & 140 & 700,00 & 98000 \\
\hline HTH & \multicolumn{2}{|c|}{17} & \multicolumn{2}{|c|}{18} & 35 & 35 & 35 & 140 & 340,00 & 47600 \\
\hline Домашній & \multicolumn{2}{|c|}{17} & \multicolumn{2}{|c|}{18} & 35 & 35 & 35 & 140 & 250,00 & 35000 \\
\hline \multicolumn{11}{|l|}{ Радіо } \\
\hline Просто радіо & \multicolumn{2}{|c|}{35} & \multicolumn{2}{|c|}{35} & 70 & 70 & 70 & 280 & 580,00 & 162400 \\
\hline Народне Радіо & \multicolumn{2}{|c|}{35} & \multicolumn{2}{|c|}{35} & 70 & 70 & 70 & 280 & 460,00 & 128800 \\
\hline Наше Радіо & \multicolumn{2}{|c|}{35} & \multicolumn{2}{|c|}{35} & 70 & 70 & 70 & 280 & 380,00 & 106400 \\
\hline \multicolumn{11}{|l|}{ Журнали } \\
\hline Теленеделя & & & 1 & & 1 & 1 & 1 & 4 & 6253,20 & 25012,80 \\
\hline \multicolumn{11}{|l|}{ Друк. Видання } \\
\hline Листівки & 800 & 200 & & & & & & 1000 & 0,50 & 500 \\
\hline Плакати & & & & & & & & 3200 & 5,00 & 16000 \\
\hline \multicolumn{11}{|l|}{ А ТАКОЖ: } \\
\hline Білборди & & & & & & & & 20 & 3000 & 60000 \\
\hline Просування сайту & & & & & & & & & & 13500 \\
\hline Банерна реклама & & & & & & & & & & 2600 \\
\hline $\begin{array}{l}\text { ВСЬОГО НА } \\
\text { РЕКЛАМНУ } \\
\text { КАМПАНІЮ }\end{array}$ & & & & & & & & & & 810676,3 \\
\hline
\end{tabular}

* авторська розробка 
Реклама у журналах запланована один раз на два місяці. Роздача буклетів припадає на початок продажів продукції (тиждень, починаючи з середини грудня).

Згідно з проведеними розрахунками, витрати на рекламну кампанію складуть 810,7 тис. грн. (табл. 2).

$$
\mathrm{ROMI}=\frac{\text { Прибуток-Витрати на рекламу }}{\text { Витрати на рекламу }}=\frac{17975,58-810,7}{810,7}=21,17
$$

Його значення перевищує 0, що свідчить про фінансову вигоду від запропонованого маркетингового бюджету на рекламну кампанію, а також є доцільним і рентабельним для підприємства.

Розрахувавши вплив запропонованого проекту переробки вторинної сировини на продукти 3 високим вмістом біологічно активних сполук на основні показники діяльності ПрАТ «Одесавинпром» встановили, що він позитивно вплине на фінансову діяльність ПрАТ «Одесавинпром». Чистий дохід (виручка) від реалізації продукції збільшиться на 51446,3 тис. грн. $(15,89 \%)$ [10].

Витрати на 1 грн. чистої виручки від реалізації зменшаться на 4,72 коп. (4,77 \%). Рентабельність продукції складе 5,1 \%, що на 3,96 пункти більше ніж до проекту.

Висновки та перспективи подальших досліджень. В умовах економічної кризи та фінансової нестабільності функціонування національної економіки в країні одним із найпріоритетніших напрямів розвитку підприємств постає впровадження у виробництво інноваційної продукції. Підгрунтям даного
ÏÏ ефективність була оцінена за допомогою показника ROMI - коефіцієнта, який вказує на рівень дохідності або збитковості рекламної кампанії, враховуючи суму бюджету на маркетингові заходи (формула 2).

напряму є стратегія, без якої неможливий інноваційний розвиток, економічне зростання.

Науковою новизною даного дослідження $є$ ефективне стратегічне планування процесу виведення на ринок інноваційного продукту з високим вмістом біологічно активних сполук на основі оцінки стану ПрАТ «Одесавинпром» на ринку вина в Україні у період економічної кризи.

Практична значущість одержаних результатів полягає в розробці комплексу функціональних маркетингових стратегій для поліпшення фінансового стану підприємства на ринку України.

Подальше вивчення питань формування маркетингової стратегії виведення на ринок інноваційного продукту на підприємстві дозволить детальніше розглянути проблеми стратегічного планування виноробних підприємств та розробити механізм впровадження комплексу стратегій.

Таким чином, активна науково-дослідна й інноваційна діяльність вчених та виробників дозволили одержати унікальний продукт, який на даний момент не має аналогів в Україні і зможе зайняти свою нішу на ринку.

\section{Література}

1. Активізація інноваційної діяльності: організаційно-правове та соціально-економічне забезпечення: монографія / Амоша О.І., Антонюк В.П., Землянкін А.І. та ін. Донецьк: НАН України. Ін-т економіки промисловості, 2007. 328 с.

2. Антонюк. Л.Л. Інновації: теорія, механізм розробки та комерціалізації: монографія. К.: КНЕУ, 2003. 394 c.

3. Галиця І. О. Що ж таке інноваційний розвиток? // Економіка та держава. 2003. № 10. С. 32-33.

4. Гринько Т.В. Проблеми формування концепції інноваційного розвитку промисловості України //Економіка промисловості. 2013. № 3 С. 163-169.

5. Зянько В.В. Інноваційне підприємництво: сутність, механізми і форми розвитку: монографія. Вінниця: Універсум-Вінниця, 2008. 397 с.

6. Інноваційні розробки ОНАХТ «Сироп 3 гребенів винограду «Здоровіт»»: [Веб-сайт]. URL: *https://www.onaft.edu.ua/download/innovat/3_14_inovate_Osipova_Lisii_ua.pdf (дата звернення: 10.08.2018).

7. Інновації в Україні: пропозиції до політичних заходів (вересень 2011). К.: Фенікс, 2011. С. 30-31.

8. Онишко С.В. Фінансове забезпечення інноваційного розвитку: монографія. Ірпінь.: Національна академія ДПС України, 2004. 434 с.

9. Про рекламу: Закон України за станом на 26.07.2018 р. [Електронний ресурс] // Сайт Верховної Ради України. URL:http://zakon.rada.gov.ua/laws/main/270/96-вр (дата звернення: 12.08.2018).

10. Річна фінансова звітність емітента: [Веб-сайт]. URL: https://smida.gov.ua/ (дата звернення: 12.08.2018). 
Лагодиенко В.В.

доктор экономических наук, профессор

E-mail: volodymyr@wiktoriya.com
Голодонюк О.М.

старший преподаватель

E-mail: kaf.mpit@gmail.com

\section{Мильчева В.В. аспирант}

кафедра маркетинга, предпринимательства и торговли

Одесская национальная академия пищевых технологий ул. Канатная, 112, г. Одесса, Украина, 65039

E-mail: milchewa.v@gmail.com

\section{СТРАТЕГИЧЕСКИЕ РЕШЕНИЯ ПРИ ПРОДВИЖЕНИИ НА РЫНОК ИННОВАЦИОННОГО ПРОДУКТА ИЗ ВТОРИЧНОГО СЫРЬЯ ВИНОДЕЛИЯ}

В данной статье рассмотрен процесс формирования стратегических решений продвижения на рынок инновационного продукта из вторичного сырья виноделия на примере ЧАО «Одессавинпром», разработаны четыре функциональные стратегии в соответствии с каждым элементом комплекса маркетинга на предприятии, приведенный пример удачно организованной рекламной кампании для продвижения нового товара производителя.

Нестабильность рыночной среды, жесткость и изменчивость его внешних и внутренних факторов требуют точного и благоразумного прогноза результатов деятельности предприятия. Низкие показатели развития инновационной сферы в Украине по сравнению с предприятиями других стран мира являются причиной низкого уровня конкурентоспособности и, как результат, неустойчивого экономического развития.

Управление инновационной деятельностью предприятия в первую очередь предусматривает обязательное непрерывное совершенствование производственного процесса путем поиска, отбора, разработки и внедрения инновационных концепций, формирования банка инновационных идей и методов их результативной реализации, выявление наиболее острых проблем инновационного развития и путей их преодоления и т.д.

Таким образом, правильно выбранная стратегия является не только результатом, но и эффективным механизмом плодотворного стратегического планирования. Она мобилизует использование научно-технического, производственно-технологического, финансово-экономического, социального и организационного потенциала предприятия в определенных направлениях, которые являются основой его конкурентоспособности.

Ключевые слова: стратегия, реклама, инновационный продукт, сироп, ЧАО «Одессавинпром», вторичное сырье виноделия.

\section{Lagodienko V.}

Doctor of Economics, Professor

E-mail:volodymyr@wiktoriya.com
Holodonyuk 0.

Assistant

E-mail: kaf.mpit@gmail.com

Milcheva V.

Postgraduate

Department of Marketing, Business and Trade

Odessa National Academy of Food Technologies

Kanatna str., 112, Odessa, Ukraine, 65039

E-mail: milchewa.v@gmail.com

\section{STRATEGIC SOLUTIONS AT PROMOTION OF THE INNOVATIVE PRODUCT FROM SECONDARY WINE-MAKING RAW MATERIALS TO THE MARKET}

This article discusses the process of forming strategic decisions to promote an innovative product from the secondary raw materials of winemaking to the market by the example of OdesaVinprom. Four functional strategies have been developed in accordance with each element of the marketing complex at the 
enterprise, an example of a well-organized advertising campaign for promoting a new product of the manufacturer.

The instability of the market environment, the rigidity and variability of its external and internal factors require an accurate and prudent forecast of the results of the enterprise activity. Low indicators of innovation sphere development in Ukraine in comparison to the enterprises of other countries of the world are the reason of low level of competitiveness and, as a result, unsustainable economic development.

The management of the innovative activity of the enterprise primarily involves the mandatory continuous improvement of the production process by searching, selecting, developing and implementing innovative concepts, forming a bank of innovative ideas and methods of their effective implementation, identifying the most acute problems of innovative development and ways to overcome them, etc.

Thus, the correctly chosen strategy is not only the result, but also an effective mechanism for fruitful strategic planning. It mobilizes the use of the scientific, technical, production-technological, financialeconomic, social and organizational potential of the enterprise in certain areas, which are the basis of its competitiveness.

Key words: strategy, advertising, innovative product, syrup, Odesavinprom Private Company, secondary raw materials for winemaking.

\section{References}

1. Amosha, O. I., Antoniuk, V. P., \& Zemliankin, A. I. (2007). Aktyvizatsiia innovatsiinoi diialnosti: Orhanizatsiino-pravove ta sotsialno-ekonomichne zabezpechennia. Donetsk: NAN Ukrainy. In-t ekonomiky promyslovosti.

2. Antoniuk, L. L. (2003). Innovatsii: Teoriia, mekhanizm rozrobky ta komertsializatsii. Kyiv: KNEU.

3. Halytsia, I. O. (2003). Shcho zh take innovatsiinyi rozvytok? Ekonomika Ta Derzhava, (10), 32-33.

4. Hrynko, T. V. (2013). Problemy formuvannia kontseptsii innovatsiinoho rozvytku promyslovosti Ukrainy. Ekonomika Promyslovosti, (3), 163-169.

5. Zianko, V. V. (2008). Innovatsiine pidpryiemnytstvo: Sutnist, mekhanizmy i formy rozvytku. Vinnytsia: Universum-Vinnytsia.

6. Innovatsiini rozrobky ONAKhT «Syrop z hrebeniv vynohradu «Zdorovit»». Retrieved August 10, 2018, from *https://www.onaft.edu.ua/download/innovat/3 14 inovate Osipova_Lisii ua.pdf

7. Innovatsii v Ukraini : Propozytsii do politychnykh zakhodiv (veresen 2011). (2011). Kyiv: Feniks.

8. Onyshko, S. V. (2004). Finansove zabezpechennia innovatsiinoho rozvytku. Irpin: Natsionalna akademiia DPS Ukrainy.

9. Zakon Ukrainy «Pro reklamu» [Redaktsiia vid 26.07.2018 r.]. (2018). Retrieved August 12, 2018, from http://zakon.rada.gov.ua/laws/main/270/96-вp

10. Smida «Richna finansova zvitnist emitenta». (2018). Retrieved August 12, 2018, from https://smida.gov.ua/

Received 15 August 2018

Approved 29 August 2018

Available in Internet 17.10.2018

Цитування згідно ДСТУ 8302:2015

Лагодієнко В.В., Голодонюк О.М., Мільчева В.В. Стратегічні рішення просування на ринок інноваційного продукту зі вторинної сировини виноробства // Економіка харчової промисловості. 2018. Т. 10, Вип. 3. С. 41-47; doi:

10.15673/fie.v10i3.1060

Cite as APA style citation

Lagodienko, V. V., Holodonyuk, O. M., \& Milcheva, V. V. (2018). Strategic solutions at promotion of the innovative product from secondary wine-making raw materials to the market. Food Industry Economics, 10(3), 41-47; doi: 10.15673/fie.v10i3.1060 